\title{
A COLOURFUL NEW SPECIES OF MYZOMELA HONEYEATER FROM ROTE ISLAND IN EASTERN INDONESIA
}

\author{
Dewi Malia Prawiradilaga ${ }^{1 \pi}$, Pratibha Baveja ${ }^{2 \pi}$, Suparno ${ }^{1}$, Hidayat Ashari ${ }^{1}$, \\ Nathaniel Sheng Rong $\mathrm{Ng}^{2}$, Chyi Yin Gwee ${ }^{2}$, Philippe Verbelen ${ }^{3}$ and Frank Erwin Rheindt* ${ }^{2}$ \\ ${ }^{1}$ Zoology Division (Museum Zoologicum Bogoriense), Research Center for Biology, Indonesian Institute of Sciences, \\ Jl. Raya Jakarta-Bogor Km 46, Cibinong, Bogor 16911, Indonesia \\ ${ }^{2}$ Department of Biological Sciences, National University of Singapore, Singapore \\ ${ }^{3}$ Krijgsgasthuisstraat 89,9000 Ghent, Belgium \\ *Corresponding author: dbsrfe@nus.edu.sg \\ "These authors contributed equally to this work
}

Received: 21 November 2017; Accepted: 30 November 2017

\begin{abstract}
The avifauna of Rote Island in the Lesser Sundas is not well studied and generally considered to be similar to that of adjacent Timor Island. However, some cases of bird endemism have recently been documented on this island. A population of Myzomela honeyeater is one such example. First observed in October 1990, it has been subsumed with Myzomela dammermani from Sumba Island given its superficially similar appearance. Based on extensive morphological inspection and bioacoustic analysis, we here describe this population as a new taxon to science. Apart from previously overlooked plumage distinctions, the new taxon bioacoustically differs from $M$. dammermani in the presence or absence of several unique call types and considerable differences across two parameters in shared call types. Considering the importance of bioacoustics in avian species delimitation, we propose that the new Rote Myzomela be considered a distinct species. Given continued habitat conversion across its small range, we propose the International Union for Conservation of Nature and Natural Resources (IUCN) threat status Vulnerable for the species.
\end{abstract}

Key words: bird, Lesser Sundas, Myzomela, new species, Rote Island

\section{INTRODUCTION}

The Wallacean region, tucked in between the Oriental and Australasian faunal regions, is fertile ground for studying evolutionary mechanisms and speciation. Recurrent sea level changes during Quaternary periods of global cooling have variably connected and isolated islands through land bridges on alternating occasions in this region (Voris 2000, Whittaker \& Fernandez-Palacios 2007, Lohman et al. 2011, Peterson et al. 2015). The avifauna of the Wallacean islands is comparatively poorly known and poses great taxonomic challenges (White \& Bruce 1986, Coates et al. 1997, Eaton et al. 2016).

Rote, a small, deep-sea, volcanic island in the Lesser Sundas with an area of 1,226 $\mathrm{km}^{2}$ (Monk et al. 1997), lies about $12 \mathrm{~km}$ south of the south-western tip of Timor (Fig. 1). As a result of this position, Rote has received comparatively little attention by biogeographers and zoologists, who have mostly assumed that its fauna will host a predominantly Timor element. However, relatively deep sea (greater than $145 \mathrm{~m}$ in depth) separates Rote from nearby Timor, leading to its permanent separation even during glacial peaks when the global sea level recedes by about $120 \mathrm{~m}$ (Bintanja et 


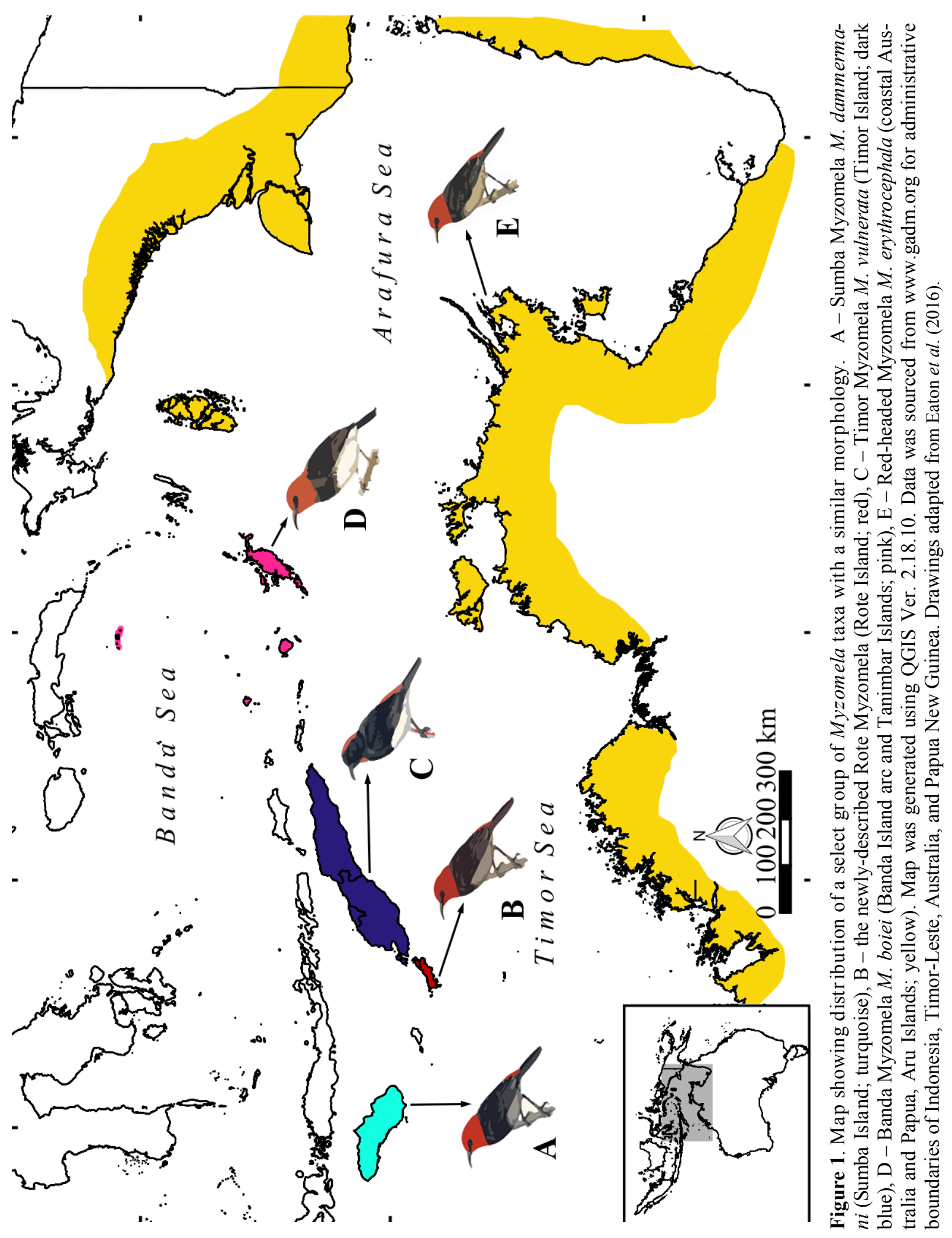


al. 2005). Therefore, some endemic element can be expected in Rote's avifauna even despite its comparatively small size and proximity to Timor (Rheindt 2016). With the general lack of ornithological studies on Rote's avifauna, the great distinctness of several avian taxa on the island remained undetected until recent work recognised Rote Boobook Ninox rotiensis and Rote Fantail Rhipidura tenkatei at the species level (Eaton et al. 2016, Gwee et al. 2017).

The first modern compilation of Rote's avifauna, based on independent surveys in 1990 and 1993, lists a total of 119 bird species for the island, most of which were unsurprisingly of Timor origin (Johnstone \& Jepson 1996). However, among Rote's birds, Johnstone \& Jepson (1996) also documented a Myzomela honeyeater population whose morphologically closest populations seemed to hail from Sumba, about $230 \mathrm{~km}$ to the west, instead of Timor, about $12 \mathrm{~km}$ to the east (Fig. 1). Although no specimens were collected, Johnstone \& Jepson (1996) emphasised further research is needed to clarify the taxonomic status of these myzomelas.

\section{History and complexity of Myzomela classification}

The honeyeater family Meliphagidae is one of the most speciose and prevalent components of the Australo-Papuan avifauna. Within this family, the genus Myzomela is a monophyletic group of small, brightly colored honeyeaters (Driskell \& Christidis 2004) comprising more than 30 species (Higgins et al. 2008), rendering it the largest genus of the family. The distribution of Myzomela ranges from Wallacea across New Guinea and Australia to Melanesia, with a high incidence of single-island endemism (Higgins et al. 2008). However, its taxonomic classification has undergone a checkered history (Table 1). There has been confusion regarding the assignment of species or

Table 1. Taxonomic treatment of a select group of red-headed myzomelas (Myzomela) with a similar morphology under different recent classifications

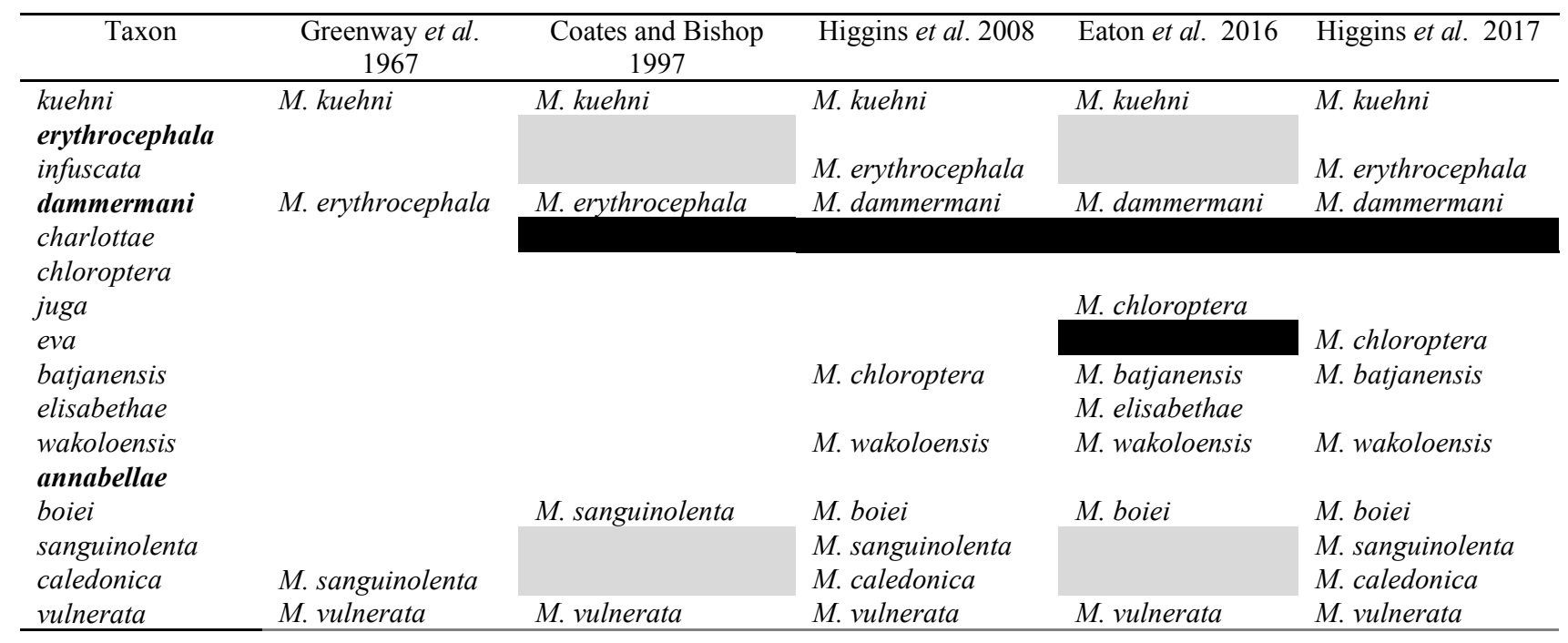

Black cells indicate taxa not recognised by a taxonomic authority; grey cells indicate that the taxon in question was outside the geographic scope of the taxonomic authority. Taxa shown in bold are considered in the present bioacoustic study (see Results). 
subspecies status to various Wallacean taxa (e.g. dammermani, wakoloensis, elisabethae, chloroptera, batjanensis; Table 1). Out of these, the Sumba Myzomela (M. dammermani) is similar to the Red-headed Myzomela (M. erythrocephala) in sexual dimorphism and has been considered conspecific with it in the past (Table 1), but differs in its extent of pigmentation and size (Higgins et al. 2008). Although $M$. dammermani is widely considered endemic to the island of Sumba, some sources (Johnstone \& Jepson 1996, Higgins et al. 2017, BirdLife 2017) consider the undescribed Myzomela population from Rote Island as part of it.

In the current contribution, we describe to science this new Myzomela honeyeater population from Rote. In our assignment to taxonomic rank, we consider morphological and bioacoustic evidence because species specific songs are often crucial in mate selection and a source of reproductive isolation in birds (Marler 1957, Searcy et al. 1981, Payne 1986, Slabbekoorn \& Smith 2002, Catchpole \& Slater 2003, Brambilla et al. 2008). In a setting such as the Lesser Sundas, the emergence of a local dialect in a newly colonised area may lead to bioacoustic divergence, followed by reproductive isolation and potential speciation (Martens 1996, Slabbekoorn \& Smith 2002, Seneviratne et al. 2012). Hence, bioacoustic analysis is a useful tool in the discovery of new species and species delimitation (Isler et al. 1998, Alström \& Ranft 2003, Ng \& Rheindt 2016, Ng et al. 2016).

\section{MATERIALS AND METHODS}

\section{Specimen and material collection}

We performed mist-netting on Rote from 28 November through 3 December 2015 (FER, HA, Suparno, DMP's personnel). The Ministry of Research and Higher Education of the Republic of Indonesia issued the research permit No: 9/TKPIPA/E5/Dit.KI/IX/2015 on 9 September 2015 to FER for the main field work. We collected four specimens of the local Myzomela population using mistnets, out of which one holotype was selected for description in this study. All four specimens were prepared as dry skins by Suparno and are deposited in the bird collection in the Museum Zoologicum Bogoriense at Cibinong (near Bogor), West Java, Indonesia (collection number of holotype MZB.Ornit.34.650). We do not believe that our collection of four specimens would have negatively impacted the survival of this species because our collection occurred in relatively good habitat in which the species remains common. However, we advocate against extensive future collections of this species and consider the present series sufficient for taxonomic inquiries.

We gathered a total of 87 sound recordings of four species of Myzomela found across Australasia in addition to the proposed new Myzomela taxon found on Rote Island, referred to as Rote Myzomela henceforth (Fig. 1). The four species, Sumba Myzomela (M. dammermani), Redheaded Myzomela (M. erythrocephala), Timor Myzomela (M. vulnerata), and Banda Myzomela ( $M$. 
boiei), were chosen based on their geographic proximity and/or morphological similarity to Rote Myzomela. Apart from our own recordings made during fieldwork on Rote and Sumba (3-7 July 2009, 15 July-15 August 2009, 29 March-2 April 2014, 23 July-6 August 2014), sound recordings were procured from various online sound libraries, such as Xeno-Canto ornithological sound collection (www.xeno-canto.org), the Avian Vocalization Centre (www.avocet.zoology.msu.edu), Internet Bird Collection (www.hbw.com/ibc), and from private sound collections of various colleagues (Table Supplement 1 ). Final recordings included were contributed by twelve different recordists.

Though different recordists used different equipment for recording, bias on parameter measurements was considered minimal because differences among recordings from the same recordist were equivalent to or sometimes exceeded those among recordings by different recordists, demonstrating that differences in recording quality are more important than equipment differences (van Balen et al. 2013). Moreover, as multiple recordings by different recordists were analysed for each taxon, such bias would be removed.

\section{Morphological work}

Colour descriptions of the holotype were carried out against the Munsell colour notation (Munsell 2000). Gape measurement was taken using a digital caliper. Bill and tarsus measurements were taken using Swiss Precision Instruments, Inc ${ }^{\mathrm{TM}}$ dial calipers, whereas wing and tail length were measured using a small wing ruler and Porzana Ltd tail ruler, respectively. Wing spread and total body length were measured using a large wing ruler. Weight was recorded using a Pesola ${ }^{\circledR M i c r o-L i n e ~ s p r i n g ~ s c a l e ~ w i t h ~ a n ~ u p p e r ~ l i m i t ~ o f ~} 100 \mathrm{~g}$.

\section{Specimens examined}

For diagnosis of the new species, specimens of congeneric taxa housed at the Museum Zoologicum Bogoriense (MZB) and selected on the basis of morphology and/or geographical proximity were compared. Specimens and collection numbers are listed according to the taxonomy by Eaton et al. (2016): the new Rote Myzomela 3 (MZB.Ornit.34.646, MZB.Ornit.34.650, MZB.Ornit.34.909); Buru Myzomela Myzomela wakoloensis 18 (MZB.Ornit.7147, MZB.Ornit.7149-7150, MZB.Ornit.7153-7155, MZB.Ornit.7158-7166, MZB.Ornit.7168, MZB.Ornit.7170-7171); Banda Myzomela M. boiei 3 (MZB.Ornit.1695, MZB.Ornit.1697, MZB.Ornit.1698); Sulawesi Myzomela M. chloroptera 3 (MZB.Ornit.1692-1694). For some species, specimens were not available, and they were compared using photographs: Seram Myzomela M. elisabethae (Oriental Bird Images: www.orientalbirdimages.org/search.php? $\mathrm{p}=2 \&$ Bird_ID $=2833 \&$ Bird_Family_ID $=$ \&pagesize=1); Timor Myzomela M. vulnerata (Oriental 
BirdImages: www.orientalbirdimages.org/search.php?Bird_Image_ID $=120780 \&$ Bird_ID $=1345 \&$ Bird_Family_ID=\&Location=); Red-headed Myzomela M. erythrocephala (Internet Bird Collection: www.hbw.com/ibc/photo/red-headed-myzomela-myzomela-erythrocephala/male-redheaded-honeyeater-foraging-mangroves). Sumba Myzomela $M$. dammermani, which is the

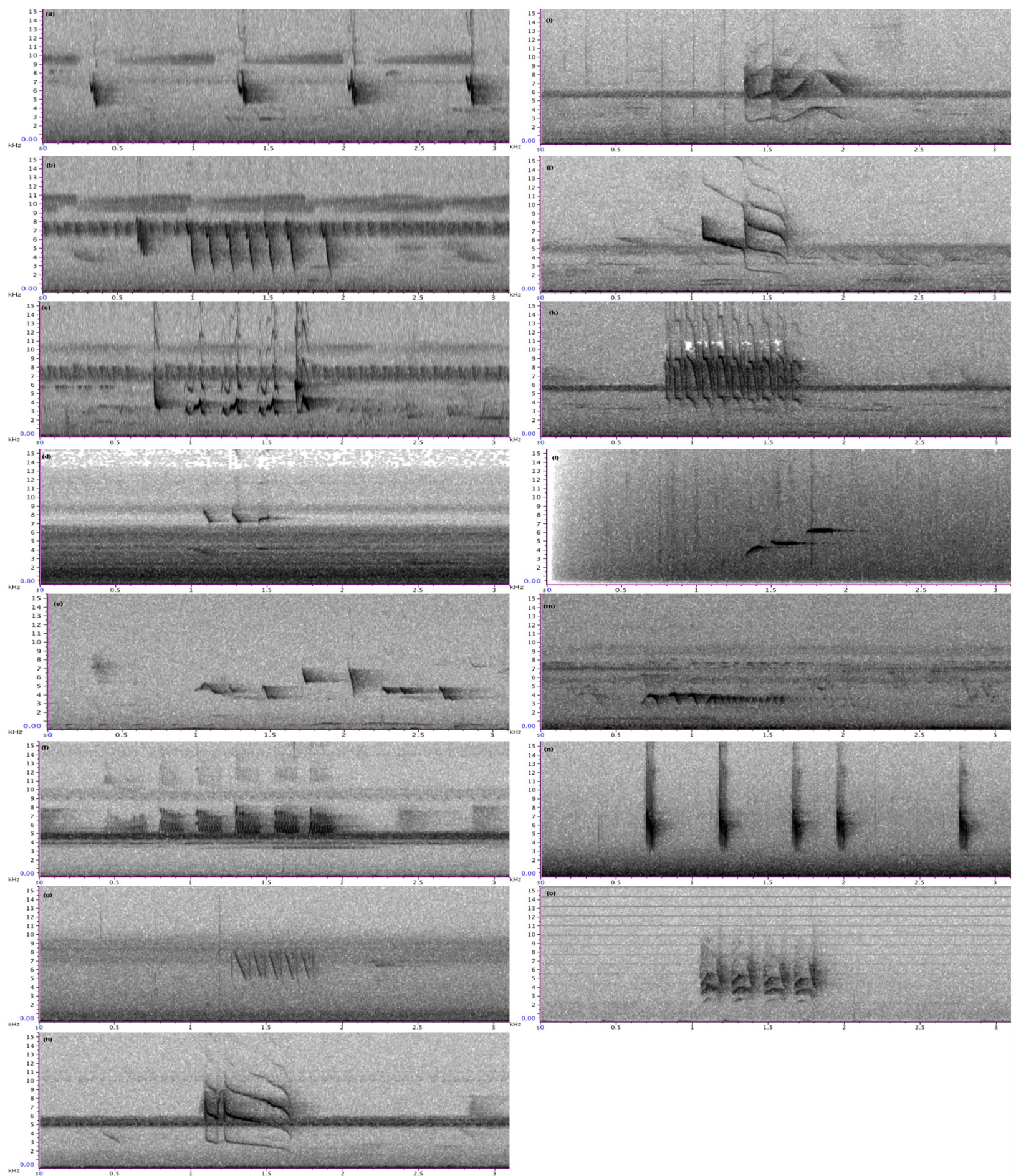

Figure 2 (a-o). Sonograms of typical examples of the 15 call types identified across five Myzomela taxa studied. Representative call types here depicted were chosen from: [a], [b], [c], [e] - the new Rote Myzomela; [d] - M. vulnerata; [f], [g], [h], [i], [j], [k] - M. dammermani; [1], [m] - M. boiei; [n], [o] - M. erythrocephala. Each call type can potentially occur in multiple species. Some call types (e.g. [b] and [g]; or [h], [i], and [j]) appear similar on the sonogram but were classified as different call types because their subjective acoustic impression was distinct and they were uttered by the same species on independent occasions without signs of clinality among one another, arguing against homology. 


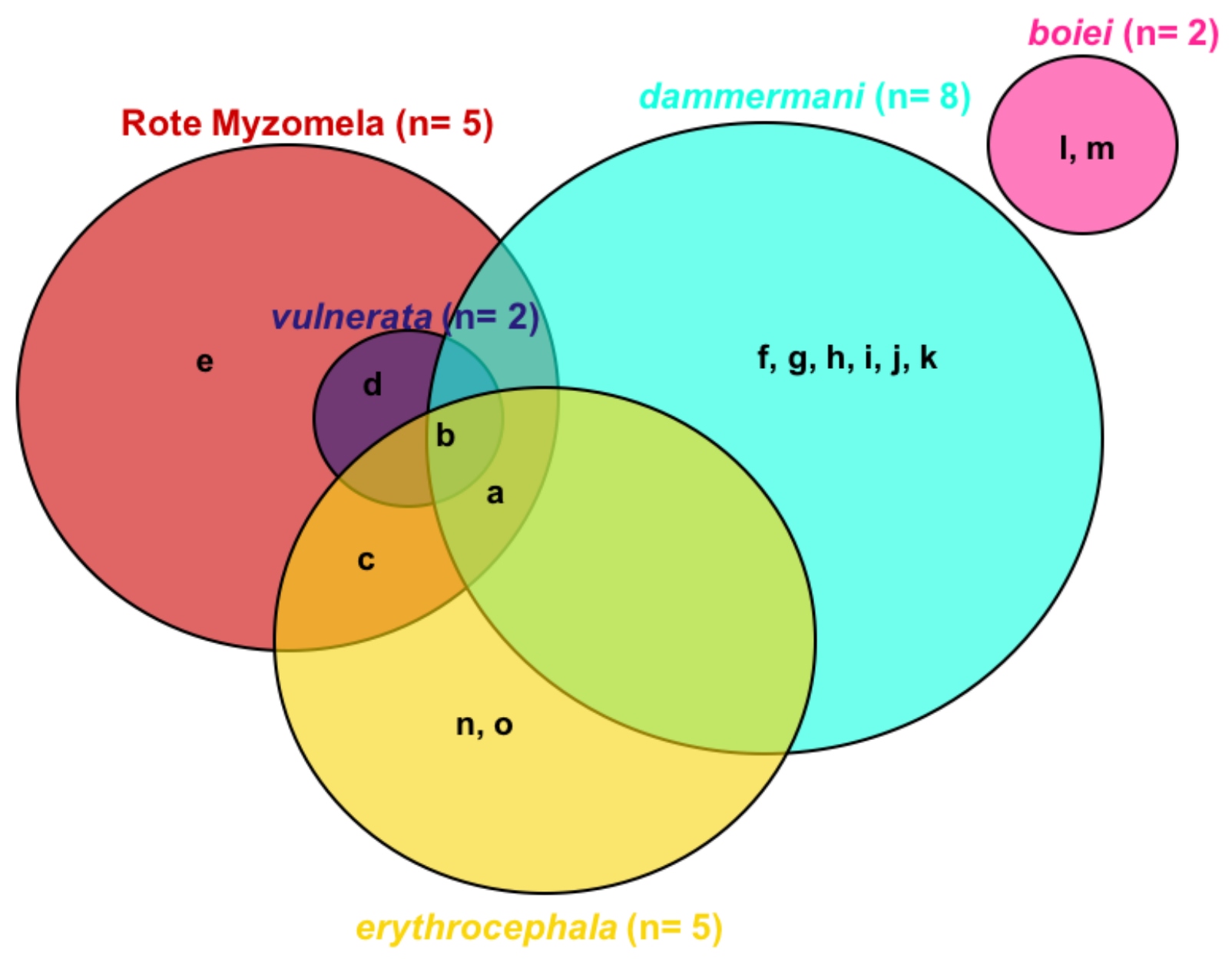

Figure 3. Venn diagram depicting overlap of call types among Myzomela taxa. Call type [b] is most widely shared (among four taxa), while call type [a] is shared among three taxa, call types [d] and [c] are shared among two taxa and all other call types are unique to one taxon.

morphologically most similar species to our new taxon, was compared using both two museum specimens (MZB.Ornit.5.178, MZB.Ornit.5.268) and numerous photos from the wild taken by and available from PV.

\section{Bioacoustic analysis}

We transformed all sound recordings into WAV format if they were originally not recorded in this format. We analysed sonograms of sound recordings using Raven Pro version 1.5 (Bioacoustics Research Program, Cornell Laboratory of Ornithology, Ithaca, NY, USA) under default settings and equal contrast and brightness. Scrutinising our bioacoustic material, we assigned recordings to various call types to ensure that only homologous call types were compared. Vocal variation in Myzomela is poorly understood, so we do not distinguish between courtship vocalisations (=songs) and other vocalisations (=calls) in this work. We found 15 different call types across the five taxa (Fig. 2), and identified overlap in call type usage among taxa (Fig. 3). Identification of call types was often unequivocal: for example, call type [a], which likely functions as a contact call, 
typically consists of a motif with a rapid chirp of a single element consisting of two discrete parts, whereas call type [b] typically consists of a series containing a variable number of identical, deflected elements (Fig. 2). On occasion, it was more difficult to ascertain whether two vocalisations represent two discrete call types or differing versions of the same call type. In these cases, we tried to be conservative with call type assignment, but proceeded to label them as different if they were uttered by members of the same population without any signs of vocal intermediacy (see, e.g., call types [b] and [g] or call types [h], [i], and [j] in Fig. 2). Using Raven, we measured temporal and frequency parameters across homologous call types [a] and [b] because they are the only two call types shared by three or more taxa (Fig. 3). We measured a total of 25 vocal parameters for call type [a] and a total of 16 vocal parameters for call type [b], amounting to 36 vocal parameters in total (Table Supplement 2). In our classification of call types, we interpreted an unbroken vocal segment as an "element", whereas a "motif" was taken to be a collection of one to multiple elements that are repeated in an almost identical fashion (Rheindt et al. 2011, Harris et al. 2014, $\mathrm{Ng}$ et al. 2016). For each vocal recording, all parameters were measured across all motif bouts so long as there were $\leq 8$ motif bouts per call type per recording. For a number of longer recordings containing more than eight motif bouts per call type, we measured a minimum of eight motifs per call bout, making sure to incorporate the maximum vocal variability present in the recording. In the end, individual measurements for each motif were averaged across the recording to arrive at one mean measurement for each call type in each recording. Principal component analysis (PCA) was performed across vocal parameters for call type [a] and call type [b], respectively, contrasting Rote Myzomela with the other Myzomela taxa. PCA was carried out using the 'prcomp' function in $\mathrm{R}$ studio, version 1.0.136 (RStudio Team 2015) while removing uninformative parameters.

Vocal parameters were also analysed using Isler et al.'s (1998) criterion for bioacoustic species delimitation (henceforth referred to as the Isler criterion). The Isler criterion has previously been applied successfully to distinguish among vocally divergent lineages of Asian and AustraloPacific doves, nightjars, bulbuls, owls, and babblers (Sangster \& Rozendaal 2004, Rheindt et al. 2011, Ng \& Rheindt 2016, Ng et al. 2016, Garg et al. 2016, Gwee et al. 2017, Cros \& Rheindt 2017). The Isler criterion was applied here to diagnose vocal divergence between Rote Myzomela and other taxa using homologous call types [a] and [b]. While Rote Myzomela also shared call types [c] and [d] with Red-headed Myzomela (M. erythrocephala) and Timor Myzomela (M. vulnerata), respectively (Fig. 3), a bioacoustic comparison using the Isler criterion was not performed based on low sample size across these call types. The Isler criterion requires two conditions for the homologous vocalisations of two populations to be considered diagnosable: 1) the range of vocal 
parameter measurements used in comparison of two taxa must not overlap, and 2) the mean and standard deviation (SD) of the measurements of taxa compared should satisfy the inequality:

$$
\mathrm{x}_{\mathrm{a}} \pm \mathrm{t}_{\mathrm{a}} \mathrm{SD}_{\mathrm{a}} \leq \mathrm{x}_{\mathrm{b}} \pm \mathrm{t}_{\mathrm{b}} \mathrm{SD}_{\mathrm{b}}
$$

where ' $a$ ' is the taxon with the smaller set of measurements, ' $b$ ' is the taxon with the larger set of measurements, $x=$ mean of all measurements, $t=$ Student's $t$-score at the 97.5 percentile at $n-1$ degrees of freedom of the $t$ distribution.

We conducted systematic playback experiments on Sumba and Rote Myzomelas using each individual's own vocalisations as well as vocalisations from the other taxon, and measured response intensity.

\section{RESULTS}

Based on our morphological and bioacoustic analyses, we here describe the unnamed population of Myzomela from Rote Island as a new species:

Myzomela irianawidodoae, species nova

English name: Rote Myzomela

Indonesian name: Myzomela Rote

Holotype: Museum Zoologicum Bogoriense, MZB.Ornit.34.650 (Fig. 4), adult male, no body or wing moult, no brood patch, all feathers fresh; collected on $30^{\text {th }}$ November 2015 by Hidayat Ashari, prepared as a dry skin by Suparno; tissue samples of pectoral muscle and liver taken and deposited at the MZB.

Type locality: Seda Forest in kecamatan (=district) Rote Selatan (=South Rote), kabupaten (=regency) of Rote Ndao, on Rote Island, in Nusa Tenggara Timur Province, Indonesia. Coordinates: $10^{\circ} 47^{\prime} 12^{\prime \prime} \mathrm{S} ; 123^{\circ} 12^{\prime} 02^{\prime \prime} \mathrm{E}$.

Etymology: We are pleased to name this species after Iriana Widodo, the current First Lady of the Republic of Indonesia, to recognise her keen interest in Indonesia's birdlife and her valuable stewardship and advocacy for Indonesia's natural environments.

\section{Description of holotype}

The holotype is a typical male Myzomela honeyeater virtually identical in shape and similar in size to the Red-headed Myzomela (M. erythrocephala) and Sumba Myzomela (M. dammermani). Measurements (taken by HA and DMP): weight $32.23 \mathrm{~g}$, wing spread $172 \mathrm{~mm}$, flattened wing length $58 \mathrm{~mm}$, total length $118 \mathrm{~mm}$, bill length $17.94 \mathrm{~mm}$, tail length $37 \mathrm{~mm}$, tarsus length 16.66 $\mathrm{mm}$, gape width $6.95 \mathrm{~mm}$. Bare parts colouration: bill wholly black; eyes dark brown; tarsus and feet black, but with yellowish-cream toe pads. Feather colouration: Bright scarlet hood (5R 4/14) 
Treubia 44: 77-100, December 2017

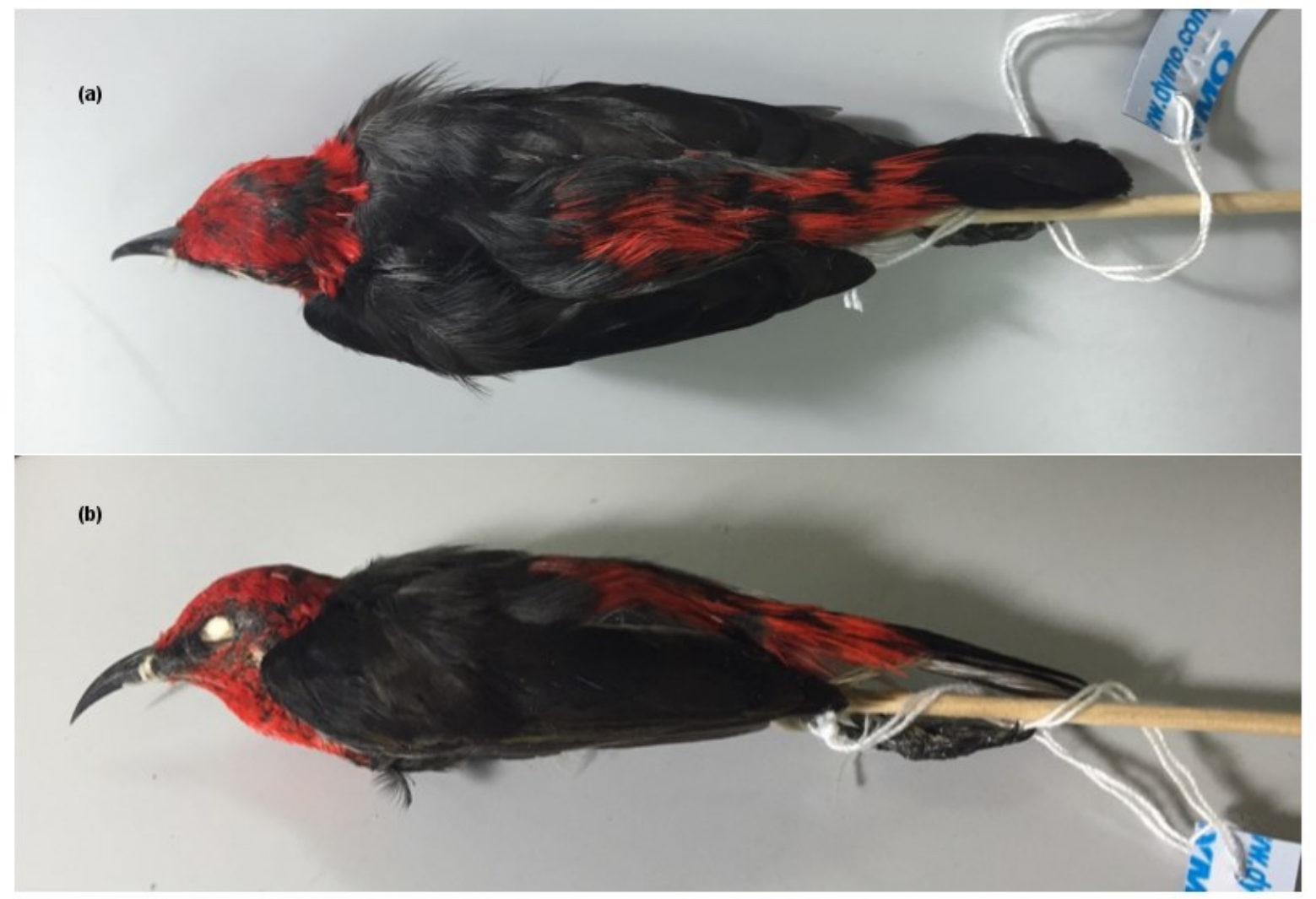

Figure 4. Dorsal (a) and lateral (b) view of the holotype (MZB.Ornit.34.650 in Museum Zoologicum Bogoriense) of the new Myzomela. 
over the head (crown, cheeks, ear coverts, chin, throat) to mid breast and nape. Black (N1) lores, extending to a thin ring around the eye. Black mid-breast band, transitioning to medium grey with an olive wash (5Y 4/2) on lower breast, belly, flanks, and vent. Black upper mantle, upperwing, and tail. Remiges (both primaries and secondaries) have black upper surfaces and slate grey (N2) undersides with inner vanes edged white. White underwing coverts. Marginal wing coverts black. Scarlet (5R 4/14) from the mid-mantle downwards, including the rump and upper tail coverts. Rectrices wholly black.

\section{Diagnosis}

A typical scarlet and black Myzomela honeyeater in male plumage, similar in size and proportion to other Wallacean myzomelas, but distinctive both vocally and in the distribution of scarlet, black, and olive-grey plumage. Akin to Red-headed (M. erythrocephala) and Sumba Myzomela (M. dammermani), which are the two morphologically closest species, the new taxon on Rote shows clear sexual dimorphism.

In the following taxon comparisons, we follow Eaton et al.'s (2016) taxonomic treatment, and we refer to adult male plumages only. The overall greyish-olive plumages of females are insufficiently characterised and cannot be safely distinguished among many species at present. In comparison with Buru Myzomela (M. wakoloensis) and Seram Myzomela (M. elisabethae):

Buru and Seram Myzomelas are told from Rote Myzomela by the extent of scarlet-red plumage; the former two have a wholly scarlet breast, belly-sides and mantle whereas the latter only has a scarlet red head with black breast band, olive grey belly, and black mantle.

In comparison with Banda Myzomela (M.boiei):

Banda Myzomela is told from Rote Myzomela by its scarlet-red (versus black) mantle and much paler whitish-grey belly. The scarlet hood of Rote Myzomela extends further down the breast than it does in Banda Myzomela.

In comparison with Sulawesi Myzomela (M. chloroptera):

Table 2. Morphometric measurements of museum specimens of Rote Myzomela and M. dammermani

\begin{tabular}{lll}
\hline Trait & Rote Myzomela $(\mathrm{n}=3)$ & M. dammermani $(\mathrm{n}=2)$ \\
\hline Bill length $(\mathrm{mm})$ & $17.8 \pm 0.3$ & $17.2 \pm 1.3$ \\
\hline Gape $(\mathrm{mm})$ & $6.5 \pm 0.5^{*}$ & $4.7 \pm 0.4^{*}$ \\
\hline Tarsus $(\mathrm{mm})$ & $17.2 \pm 0.5^{*}$ & $15.4 \pm 0.7^{*}$ \\
\hline Tail length $(\mathrm{mm})$ & $37.3 \pm 0.6^{*}$ & $35.5 \pm 0.7^{*}$ \\
\hline
\end{tabular}

Mean \pm standard deviation; $\mathrm{n}$ listed with taxon name refers to number of individuals included; *variables are significantly different at $\mathrm{p} \leq 0.05$ (Student's $\mathrm{t}$ test). 


\section{a)}
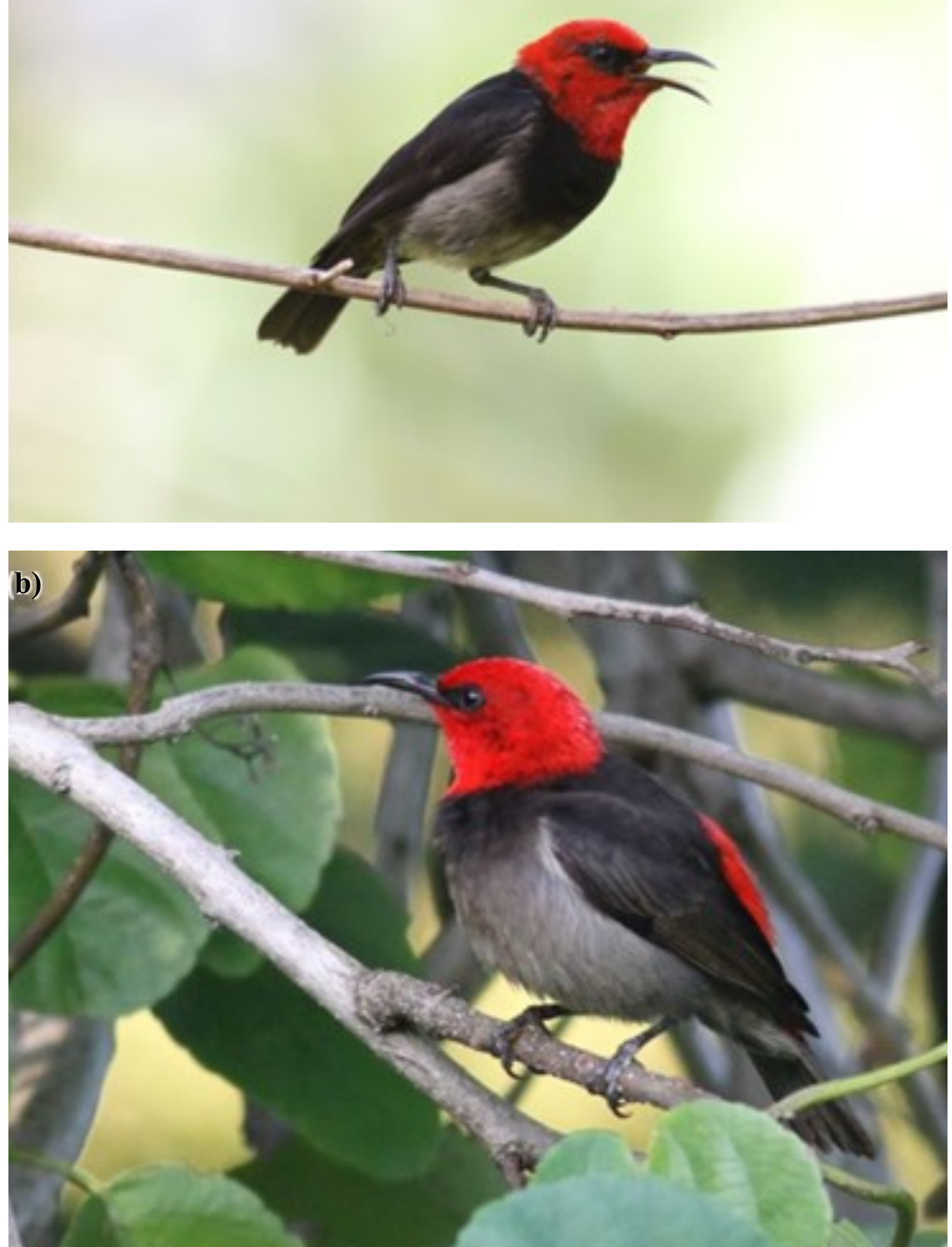

Figure 5. Pictures demonstrating the extent of difference in width of the black breast band between Rote and Sumba Myzomelas. a) Sumba Myzomela (Myzomela dammermani), and b) the new Rote Myzomela (photos by PV). 
Sulawesi Myzomela is distinguished from Rote Myzomela by its scarlet (versus black) mantle, back, and breast. The greyish-white belly and flanks of Sulawesi Myzomela are much paler than the olive-washed grey of Rote Myzomela.

In comparison with Sumba Myzomela (M. dammermani):

Sumba Myzomela is the morphologically most similar taxon to Rote Myzomela. Out of the morphometric traits compared, gape width, tarsus length, and tail length of Rote Myzomela were significantly longer than in Sumba Myzomela (Table 2), although sample sizes were generally low. The two taxa can be differentiated bioacoustically (see below) and by the extent of the black breast band. In Sumba Myzomela, the black colouration extends down from the breast to the mid-belly whereas in Rote Myzomela the black breast band is relatively narrow and does not extend to the belly (Fig. 5).

In comparison with Timor Myzomela (M. vulnerata):

Despite its geographic proximity, Timor Myzomela is easily differentiated from Rote Myzomela by the black facial mask (lores, cheeks, ear coverts, sides of neck) which joins up with the black breast band and mantle, restricting scarlet-red to two separate patches at the top of the head (crown and nape) and at the chin/throat, whereas Rote Myzomela has a wholly red head. Timor Myzomela also has a white to whitish lower breast and belly, in contrast to Rote Myzomela's olive-grey belly and lower breast.

In comparison with Red-headed Myzomela (M. erythrocephala):

Red-headed Myzomela is very similar in colouration to both Sumba and Rote Myzomelas, but can be distinguished by its caramel belly colour in contrast to the darker olive-grey belly colouration of both Rote and Sumba Myzomelas. The black colour of the breast band is slightly more diffuse and interspersed with lighter grey tones in the Red-headed Myzomela, creating the impression of a paler breast band.

\section{Vocal differences}

Analysing 87 recordings across five Myzomela taxa chosen for their geographic and/or phenotypic proximity to the newly described taxon, we categorised 15 different call types (Fig. 2) and identified overlap of call type usage across the five taxa (Fig. 3). Rote Myzomela, Sumba Myzomela, and Red-headed Myzomela exhibited 1, 6, and 2 unique call types, respectively. No unique call type was found in Timor Myzomela, whereas Banda Myzomela's vocalisations were found to be all unique, with no homologous calls shared with other taxa (Fig. 3).

These results firstly indicate that Myzomela species of Nusa Tenggara are bioacoustically 
quite diverse, with each species having a repertoire of multiple vocalizations. Secondly, these results attest to an extensive shared vocal repertoire among Nusa Tenggara's Myzomela species. For instance, Timor Myzomela is undoubtedly the most distinctly colored taxon we have examined (see Diagnosis), yet we did not detect a single call type that would be unique for this taxon (Fig. 3), differences in vocal sample size notwithstanding. Even so, most species do seem to evolve at least some unique call types not found in neighbouring species (Fig. 3). While our detection of those unique call types would sometimes be hampered by low sample size for some species, the main focus of our analysis (supported by the highest sample sizes) was the comparison of Sumba and Rote Myzomelas, the two morphologically most similar forms. Hence, we are confident that the identification of six unique Sumba call types and one unique Rote call type cannot all be explained by low vocal sampling. There are, therefore, several unique call types not shared between these two morphologically similar taxa, and these may serve as important traits in species cohesion and reproductive isolation.

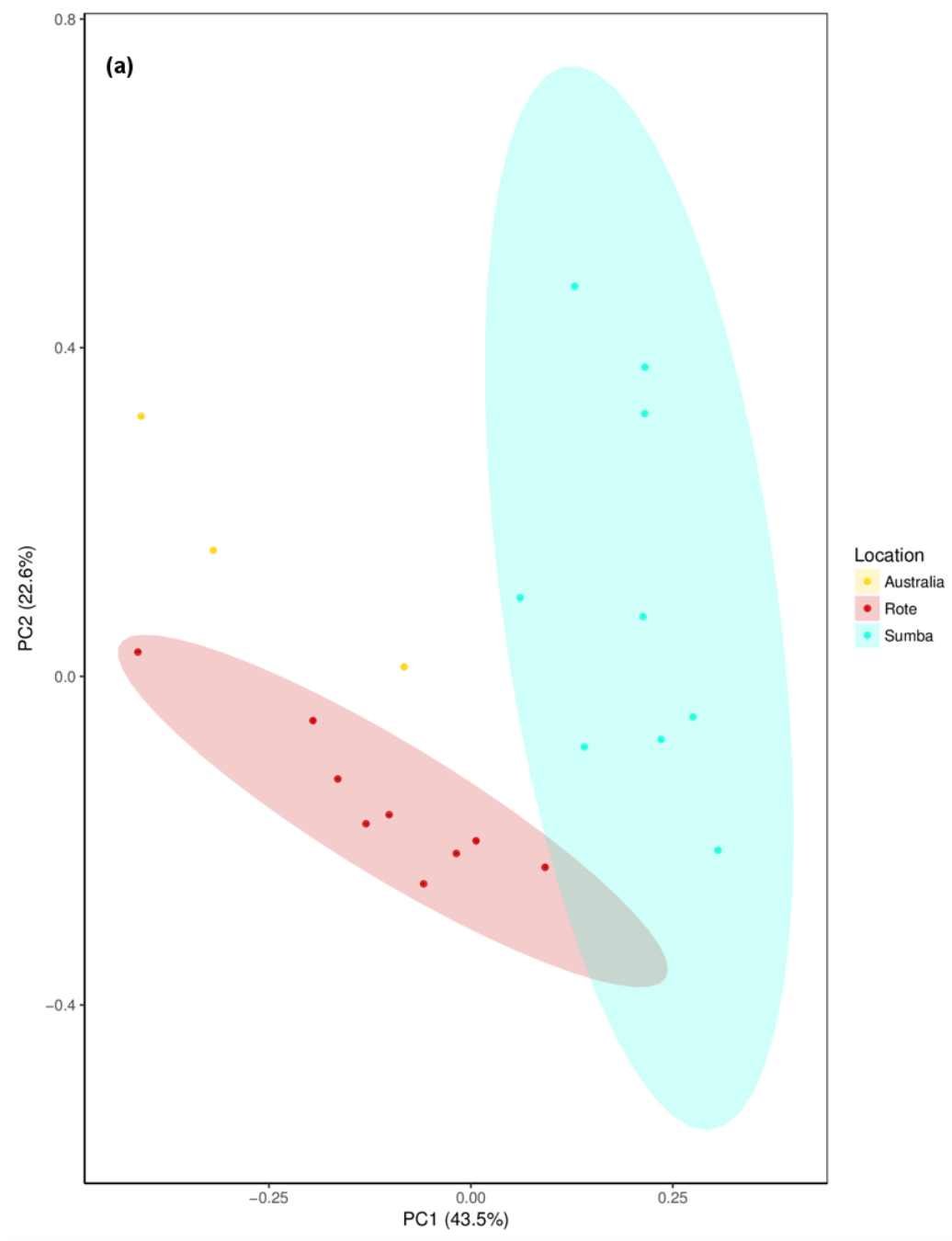




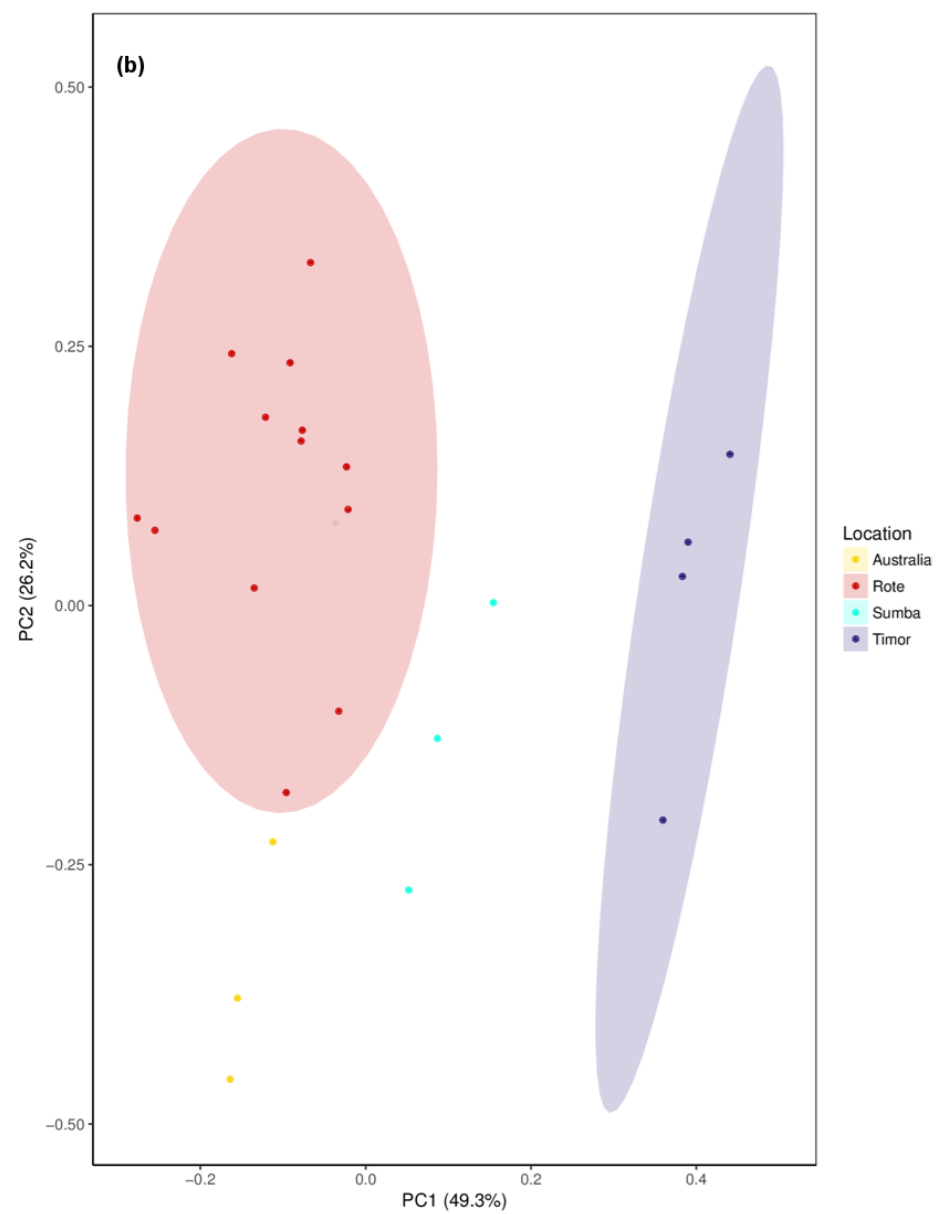

Figure 6. Principal component analysis (PCA) using all acoustic parameters. Principal components 1 and 2 (PC1 and PC2) accounted for a combined $>65 \%$ of observed variability in both analyses using call type [a] and [b], with the remaining PCs accounting for less variation, and hence being less informative. a) PCA using call type [a] for Rote Myzomela, Sumba Myzomela (M. dammermani), and Red headed Myzomela (M. erythrocephala; Australia) with 95\% confidence ellipses for taxa with a sufficient sample size (n>3). b) PCA using call type [b] for Rote Myzomela, Sumba Myzomela (M. dammermani), Timor Myzomela (M. vulnerata), and Red-headed Myzomela (M. erythrocephala; Australia) with $95 \%$ confidence ellipses for taxa with a sufficient sample size $(n>3)$.

For those call types that are shared among a substantial number of species, we performed an in-depth comparison of 36 different parameters in total, determining whether there are important differences or commonalities in the ways each taxon utters these homologous calls. One way to assess these differences was through PCA, which demonstrated that Rote and Sumba Myzomelas are largely separated for both call type [a] and call type [b] across the parameter space investigated (Fig. 6).

We also used the Isler criterion to compare 25 and 16 different acoustic parameters between Rote Myzomela and other taxa for call types [a] and [b], respectively. Between Rote Myzomela and Sumba Myzomela, Isler criterion analysis indicated complete diagnosability in one acoustic parameter each for call types [a] and [b]. Between Rote Myzomela and Timor Myzomela, Isler criterion analysis indicated complete diagnosability in five acoustic parameters for call type [b], while call type [a] is not present in Timor Myzomela. No complete diagnosability was detected in 
Table 3. Diagnosability in acoustic parameters indicated by application of the Isler criterion for call type [a]

Bioacoustic parameters

Taxon comparison

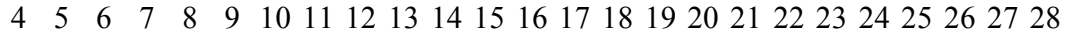

M.Rote Myzomela/M. dammermani

$\mathrm{X}$

M.M.Rote Myzomela/ M. erythrocephala

Bioacoustic parameters are numbered following Table Supplement 2.

Table 4. Diagnosability in acoustic parameter s indicated by application of the Isler criterion for call type [b]

\begin{tabular}{|c|c|c|c|c|c|c|c|c|c|c|c|c|c|c|c|c|}
\hline \multirow[b]{2}{*}{ Taxon comparison } & \multicolumn{16}{|c|}{ Bioacoustic parameters } \\
\hline & 1 & 2 & 3 & 4 & 5 & 6 & 7 & 8 & 29 & 30 & 31 & 32 & 33 & 34 & 35 & 36 \\
\hline Rote Myzomela/M. dammermani & & & & $\mathrm{X}$ & & & & & & & & & & & & \\
\hline Rote Myzomela/M. erythrocephala & & & & & & & & & & & & & & & & \\
\hline Rote Myzomela/M. vulnerata & & & & & $X$ & & & $\mathrm{X}$ & & $\mathrm{X}$ & & & $\mathrm{X}$ & & $\mathrm{X}$ & \\
\hline
\end{tabular}

Bioacoustic parameters are numbered following Table Supplement 2.

the call types shared between Rote Myzomela and Red-headed Myzomela using the Isler criterion. Furthermore, there were no homologous call types between Rote Myzomela and Banda Myzomela, which were, hence, not compared (Tables 3 and 4). Given the Isler criterion's known conservatism and susceptibility to type II errors under low sample sizes (Isler et al. 1998, Rheindt et al. 2011, Cros \& Rheindt 2017), we believe that the detection of complete diagnosability in at least one character between Rote and Sumba Myzomelas points to deep levels of bioacoustic differentiation in two species that have remained morphologically similar.

In summary, Rote Myzomela can be vocally distinguished from species on neighbouring islands by a combination of unique call types not shared with each other and discrete diagnosability across two parameters in the call types that they do share. When comparing Rote Myzomela to Sumba Myzomela, which most resembles the former in plumage coloration, there are seven call types uttered by one of these two species and not shared by the other, and there is complete parameter diagnosability in one parameter each of the two call types shared by these two species (Fig. 3; Tables 3 and 4), all of which attest to Rote Myzomela's deep level of vocal differentiation.

\section{Playback experiments}

Honeyeaters generally respond strongly to playback of their own song as it elicits intraspecific aggression among competing males (Higgins et al. 2008). Our repeated playback experiments confirmed that this is also the case with the myzomelas on Rote and Sumba. The songs of Rote 
Myzomela and Sumba Myzomela were played for about 30-40 seconds with a gap of 15-20 minutes and a strong response was usually observed. On Rote, PV carried out playback experiments on at least three different males (a conservative estimate accounting for possible double counting of individuals) from 29 March - 1 April 2014. On 28 July and 1-3 August 2014, PV and Veerle Dossche conducted similar playback experiments on Sumba on at least six different males (again a conservative estimate). Playback of their own song always triggered male birds to start singing frequently and aggressively, and they tried to approach the source of the sound. Both populations did not respond to playback of the other population at all. This lack of response to vocalisations of the other taxon strongly corroborates our previous conclusion that Rote and Sumba Myzomela are distinct at the species level.

\section{DISCUSSION}

A combination of plumage features and bioacoustic characters strongly suggest that the new taxon of Myzomela from Rote Island is distinct at the species level. In the following, we discuss its biology and status.

\section{Habitat and Distribution}

There are substantial differences in habitat use by the Red-headed Myzomela, which essentially occurs in mangroves and adjacent woodlands, compared to both the Myzomela species on Sumba and Rote, which appear to prefer forest, edge and dry woodlands with flowering trees. On Rote, myzomelas were found feeding frequently on flowers of teak trees around villages, but they predominantly inhabit forests as well as scrubby areas.

Rote Myzomela has been recorded at various locations on Rote Island. Johnstone and Jepson (1995) found it near the island's capital, Ba'a, in 1990 (Fig. 7). Field observations were made by PV and Veerle Dossche in the Sotimori / Bolatena - Daurendale village area on northern Rote in 2009 and 2014 (Fig. 7). A subsequent field visit in 2015 by FER, HA, Suparno and DMP's personnel led to the collection of the holotype at Seda forest (South Rote; Fig. 7) and additional observations around Bolatena. From all these records, it appears that Rote Myzomela is widespread across Rote Island (Fig. 7).

\section{Behaviour and Sex Ratio}

Both the myzomelas from Rote and Sumba perform song flights, described as typical for some honeyeaters (Higgins et al. 2008). On Sumba, we regularly observed birds singing in flight above the forest canopy and performing brief $(=\sim 3 \mathrm{sec})$ parachute flights by suspending their wing beats for a short while and gliding just before landing. 


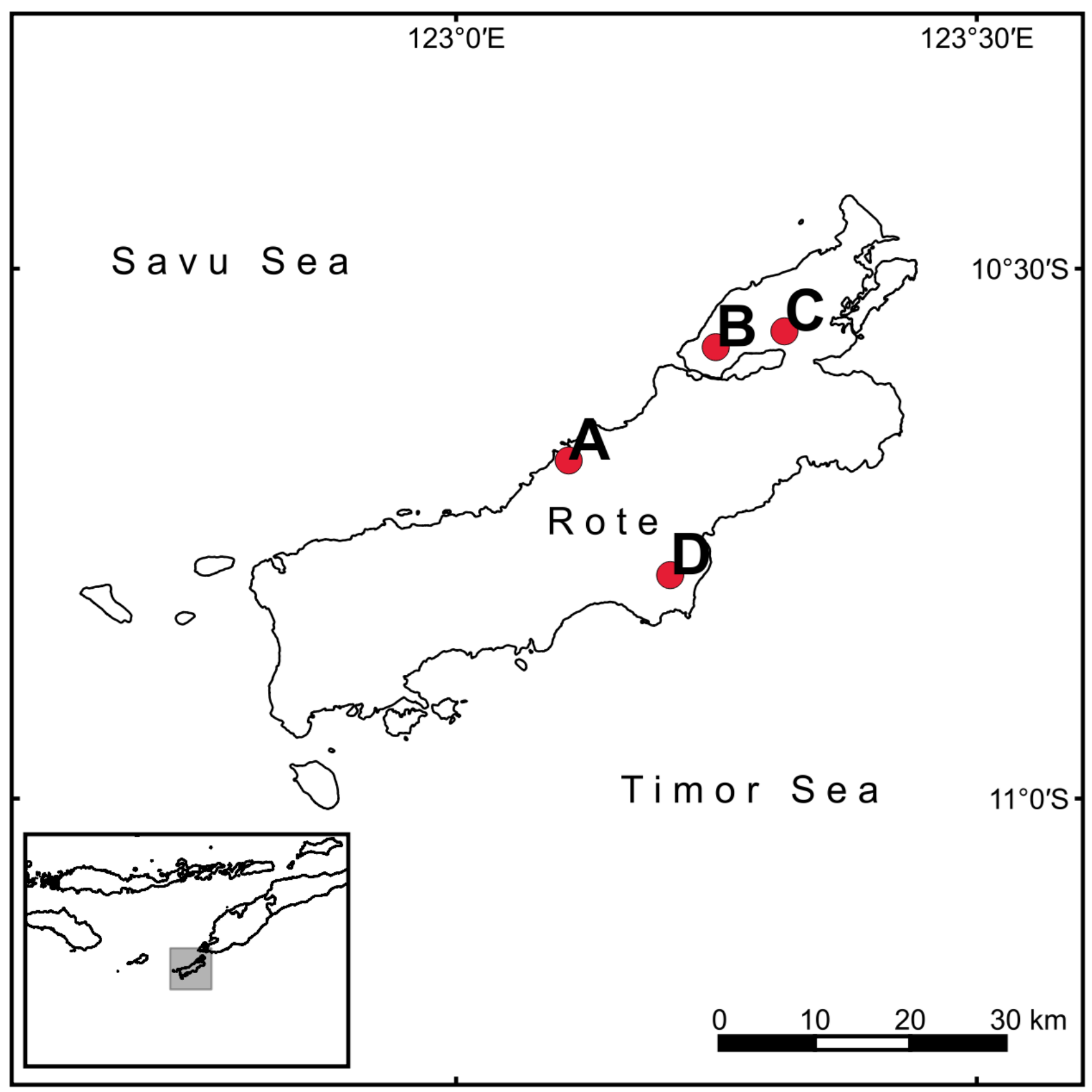

Figure 7. Localities where Rote Myzomela has been recorded on Rote Island. A) near capital Ba'a (Johnstone \& Jepson 1996), B) Bolatena (by PV, FER, HA \& Suparno), C) Sotimori (by PV), and D) Seda forest (by FER, HA \& Suparno). Map was generated using QGIS Ver. 2.18.10. Data was sourced from www.gadm.org for administrative boundaries of Indonesia and Timor-Leste. 
Both on Sumba and on Rote, more adult males were observed than female birds. This gender imbalance could partly be explained by the fact that males of both Sumba and Rote Myzomelas are more conspicuous than females in plumage, behaviour and vocalisations. However, prolonged observations in areas across Wanggameti National Park where Sumba Myzomelas were common and frequently observed at flowering trees still resulted in fewer observations of female myzomelas. On occasion, up to 3-4 adult males were seen simultaneously feeding in the same tree. Whether this skewed sex ratio is real or an observational bias related to males' more aggressive behaviour and dominance over resource-rich flowering trees is an open question. Even during our mistnetting on Rote, three adult males of Rote Myzomela entered the mistnets in comparison to only one female individual. Similar patterns in sex ratio have been observed in the Red-headed Myzomela (Higgins et al. 2008).

\section{Conservation and IUCN Status}

Most of Rote Island had been heavily deforested by 1990 (Johnstone \& Jepson 1996). Forest clearing might have an adverse impact on Rote Myzomelas because their population densities may be higher in taller forest than in low scrub. Some Pacific island species of Myzomela have been reported to show a declining population trend in the wake of deforestation (Amar et al. 2008), which may equally be demonstrated for the Rote Myzomela once it has been studied more intensely. The Rote Myzomela is especially vulnerable to threats of habitat destruction because of its narrow endemicity to Rote Island, which is only $1,226 \mathrm{~km}^{2}$ in size. Nationally, members of the genus Myzomela, including the Rote Myzomela, are protected by Indonesian Law (Undangundang) No. 5 year 1990 and Government Regulations (PP) No. 7 year 1999 (Departemen Kehutanan 2007).

Rote does not have any major terrestrial protected area (Rhodin et al. 2008). The natural resources of Rote face challenges of deforestation and land use changes because of a burgeoning human population, possibly exacerbated by the impact of growing tourism (Wright \& Lewis 2012). Conversion of forests to agricultural fields, which are the main source of income for a population of the size of 119,908 inhabitants, is certain to have a growing effect on the habitats of the Rote Myzomela (BPS NTT 2010). All these factors would call for serious conservation efforts. We suggest the IUCN category Vulnerable for Rote Myzomela based on criteria VU B2b(ii)c(ii) of the IUCN (2001) Red List criteria for threatened species. Detailed surveys of Rote Myzomela population size and degree of fragmentation on Rote Island are required for an assessment of future conservation measures. However, reassuringly the Rote Myzomela is still one of the commonest bird species in undisturbed or lightly disturbed forest and scrub habitat, such as the localities visited 
during our fieldwork, indicating healthy population levels in intact areas. When suitable tree species are in seasonal bloom, the species is frequently recorded to enter villages or degraded shrubby areas, attesting to habitat destruction being the major factor that may lead to its endangerment rather than the occasional harvest of individuals for the bird trade.

\section{Biogeography}

Myzomelas across Wallacea are generally little known and their taxonomy requires further study. As early as 1879, Forbes (1879) commented that many new species of Myzomela are yet to be discovered. Older Myzomela classifications are largely based on morphology-dominated assessments of early museum taxonomists (Forbes 1879, Koopman 1957, Greenway et al. 1967), who may have felt more comfortable to unite vicariant forms as subspecies of a larger, overarching species. However, novel demonstrations of deep bioacoustic differentiation increasingly cast such older treatments into doubt (see present work). Further study based on morphological, vocal and DNA data will be required across many taxa to shed light on Myzomela taxonomy.

Based on Isler's criterion and PCA results, the vocalisations of Rote Myzomela appear to differ more strongly from the calls of the Sumba Myzomela than from those of the Red-headed Myzomela from Papua and Australia ( 450km east and south of Rote) (Figs. 3 and 6; Tables 3 and 4). Overall, there is much less vocal variation in Rote Myzomela than in Red-headed and Sumba Myzomelas, as the former's calls appear more monotonous, uniform, and repetitive. Playback experiments confirm a strong response to conspecific song versus a lack of response to nonconspecific song in both Rote and Sumba Myzomelas, suggesting their status as independent biological species.

Given the presence of Myzomela species on highly oceanic islands of the Pacific Ocean, the genus may be characterised by an ability to traverse large areas of open sea and colonise islands (Koopman 1957), undergoing frequent speciation via overwater dispersal. Concomitant islandspecific differences in calls might act as a precursor to reproductive isolation and speciation after the colonisation of islands (Price 1998, Grant 2001).

The presence of a distinct species of Myzomela honeyeater on Rote is of biogeographic significance. Despite the relative proximity of Rote to Sumba $(\sim 230 \mathrm{~km})$, both islands are separated by a deep-sea trench $(>1000 \mathrm{~m})$ and therefore would not have been appreciably closer during recent glacial periods (Voris 2000). Consequently, the avifaunas of Sumba and Rote show little similarity (Cartensen \& Olsen 2009, Trainor 2010). It is therefore likely that myzomelas on Rote colonised the island via overwater dispersal. Despite being separated by only $12 \mathrm{~km}$ from Timor, Rote Myzomelas are much less similar to Timor Myzomelas in bioacoustic and morphological traits (Figs. 1 and 6; Table 4), rendering unlikely a close relationship between these two species. 
There have been few bioacoustic studies of honeyeaters as detailed as the present analysis (Higgins et al. 2008). Although the Myzomela population on Rote was provisionally considered the same species as Sumba Myzomela based on similar plumage in previous work (Johnstone \& Jepson 1996), the clear differences between the vocalisations of these two taxa hint at substantial divergence (Figs. 3 and 6; Tables 3 and 4). Our study demonstrates the importance of bioacoustic data in species diagnosis when morphological distinctions are limited. Vocalisations can be a more reliable taxonomic indicator in some birds than morphological traits (Rheindt et al. 2008) and should therefore be taken into account in discussions about species limits. Vocal comparisons across Myzomela species may be instrumental in unraveling the challenging taxonomy of these birds across Wallacea. Considering the important role vocalisations play in mate selection, our study provides strong support for a treatment of the Rote Myzomela at the species level.

\section{ACKNOWLEDGMENTS}

FER acknowledges funding by a Singapore Ministry of Education grant (WBS R-154-000658-112). The Research Centre for Biology-LIPI was the official sponsor of the research. We thank the East Nusa Tenggara Forestry Office (BKSDA Nusa Tenggara Timur) for issuing transport permit of the bird specimens from Rote Island to the Museum Zoologicum Bogoriense-LIPI. PV thanks the Yohannis family in Sotimori village (Rote), the community of Lorendja at the edge of Wanggameti National Park (Sumba), Veerle Dossche and Colin Trainor for their help and support. Peter and Erwin Collaerts and Stijn Cooleman shared information of their myzomela observations on Rote, and James Eaton shared Sumba Myzomela recordings that were also used for the playback experiments on Rote. Matthew Medler from the Macaulay Library at the Cornell Lab of Ornithology facilitated access to David Stewart's Red-headed Myzomela recordings. Graeme Chapman also shared recordings of the Red-headed Myzomela. Pak Rens Maku from Bolatena village is acknowledged for having assisted various co-authors with fieldwork on Rote during multiple visits. We acknowledge constructive comments by Kritika Garg, Elize Ng and Seshadari KS.

\section{REFERENCES}

Alström, P. \& R. Ranft 2003. The use of sounds in avian systematics and the importance of bird sound archives. Bulletin British of Ornithologists' Club 123A (Supplement): 114-135.

Amar, A., F. Amidon, B. Arroyo, J.A. Esselstyn \& A.P. Marshall 2008. Population trends of the forest bird community on the Pacific Island of Rota, Mariana Islands. Condor 110 (3): 421-427.

Bintanja, R., R.S. van de Wal \& J. Oerlemans 2005. Modelled atmospheric temperatures and global sea levels over the past million years. Nature 437 (7055): 125-128. 
BPS NTT 2016. Number of Population by Regency/City 1980, 1990, 2000, 2010, 2011-2016. Census Result. 2010. Available from: http://ntt.bps.go.id/linkTableDinamis/view/id/360 [Accessed 10 November 2017].

Brambilla, M., O. Janni, F. Guidali \& A. Sorace 2008. Song perception among incipient species as a mechanism for reproductive isolation. Journal of Evolutionary Biology 21(3): 651-657.

Cartensen, D.W. \& J.M. Olsen 2009. Wallacea and its nectarivorous birds: Nestedness and modules. Journal of Biogeography 36(8): 1540-1550.

Catchpole, C.K. \& P.J. Slater 2003. Bird song: biological themes and variations. Cambridge: Cambridge University Press.

Coates, B.J., K.D. Bishop \& D. Gardner 1997. A guide to the Birds of Wallacea: Sulawesi, the Moluccas, and Lesser Sunda Islands, Indonesia. Dove Publications.

Cros, E. \& F.E. Rheindt 2017. Massive bioacoustic analysis suggests introgression across Pleistocene land bridges in Mixornis tit-babblers. The Journal of Ornithology 158(2): 407-419. doi: 10.1007/s10336016-1411-x.

Departemen Kehutanan 2007. Laws on Forest Protection and Nature Conservation (in Indonesia). Jakarta: Secretariate of Directorate General of Forest Protection and Nature Conservation.

Driskell, A.C. \& L. Christidis 2004. Phylogeny and evolution of the Australo-Papuan honeyeaters (Passeriformes, Meliphagidae). Molecular Phylogenetic \& Evolution 31(3): 943-960.

Eaton, J.A., B. van Balen, N.W. Brickle \& F.E. Rheindt 2016. Birds of the Indonesian Archipelago: Greater Sundas and Wallacea. $1^{\text {st }}$ ed. Barcelona: Lynx Edicions.

Garg, K.M., R. Tizard, N.S.R. Ng, E. Cros, A. Dejtaradol, B. Chattopadhyay, N. Pwint, M. Packet \& F.E. Rheindt 2016. Genome-wide data help identify an avian species-level lineage that is morphologically and vocally cryptic. Molecular Phylogenetics \& Evolution 102: 97-103.

Grant, P.R. 2001. Reconstructing the evolution of birds on islands: 100 years of research. Oikos 92(3): 385403.

Greenway, J.C., E. Mayr, R.E. Moreau, A.L. Rand, F. Salomonsen \& D.W. Snow 1967. Check-list of birds of the world: a continuation of the work of James L. Peters. Paynter R.A. (ed.). Cambridge: Harvard University Press.

Gwee, C.Y., L. Christidis, J.A. Eaton, J.A. Norman, C.R. Trainor, P. Verbelen \& F.E. Rheindt 2017. Bioacoustic and multi-locus DNA data of Ninox owls support high incidence of extinction and recolonisation on small, low-lying islands across Wallacea. Molecular Phylogenetics \& Evolution 109: 246-258.

Harris, J.B.C., P.C. Rasmussen, D.L. Yong, D.M. Prawiradilaga, D.D. Putra, P.D. Round \& F.E. Rheindt 2014. A new species of Muscicapa flycatcher from Sulawesi, Indonesia. PloS One.; 9(11):e112657.

Higgins, P., L. Christidis, H. Ford \& A. Bonan 2008. Family Meliphagidae (Honeyeaters). In: del Hoyo, J., A. Elliott, J. Sargatal, D.A. Christie, E. de Juana (eds.), Handbook of the Birds of the World, Penduline -tits to Shrikes, vol. 13. Barcelona: Lynx Edicions, pp. 498-691.

Higgins, P., L. Christidis L, H. Ford H \& A. Bonan 2017. Honeyeaters (Meliphagidae). In: del Hoyo, J., A. Elliott, J. Sargatal, D.A. Christie \& E. de Juana (eds.), Handbook of the Birds of the World Alive. Lynx Edicions, Barcelona. Available from: http://www.hbw.com/ [Accessed 10 November 2017].

Isler, M.L., P.R. Isler \& B.M. Whitney 1998. Use of vocalizations to establish species limits in antbirds (Passeriformes: Thamnophilidae). Auk 115(3): 577-590.

IUCN 2001. The IUCN Red List of Threatened Species. Categories and Criteria. Ver. 3.1. Available from: http:// www.iucnredlist.org/static/categories_criteria_3_1 [Accessed 10 November 2017].

Johnstone, R.E. \& P. Jepson 1996. The birds of Roti island, Nusa Tenggara, Indonesia. Western Australian National 21: 23-36. 
Koopman, K.F. 1957. Evolution in the genus Myzomela (Aves: Meliphagidae). Auk 74(1): 49-72.

Lohman, D.J., M. de Bruyn, T. Page, K. von Rintelen, R. Hall, P.K.L. Ng et al. 2011. Biogeography of the Indo-Australian Archipelago. Annual Review of Ecology Evolutionary Systematics 42(1): 205-226.

Marler, P. 1957. Specific distinctiveness in the communication signals of birds. Behaviour 11(1): 13-38.

Martens, J. 1996. Vocalizations and speciation of Palearctic birds. In: Kroodsma D.E. \& E.H. Miller (eds.), Ecology and evolution of acoustic communication in birds. Cornell University Press, New York, pp. 221-240.

Monk, K.A., Y. De Fretes \& G. Reksodiharjo-Lilley 1997. The Ecology of Nusa Tenggara and Maluku. The Ecology of Indonesia Series, vol. V. Periplus Editions, Singapore.

Munsell, A.H. 2000. Munsell soil color charts, revised edition. Grand Rapids, MI: Munsell Color.

Ng, N.S.R. \& F.E. Rheindt 2016. Species delimitation in the White-faced Cuckoo-dove (Turacoena manadensis) based on bioacoustic data. Avian Research 7(1): 2.

Ng, E.Y.X., J.A. Eaton, P. Verbelen, R.O. Hutchinson \& F.E. Rheindt 2016. Using bioacoustic data to test species limits in an Indo-Pacific island radiation of Macropygia cuckoo doves. Biological Journal of Linnean Society of London 118(4): 786-812.

Payne, R.B. 1986. Bird songs and avian systematics. In: Johnston, R. (ed.), Current Ornithology. vol 3. Springer, Boston, pp. 87-126.

Peterson, A.T., R.G. Moyle, F. Lei, L.C. Campillo, P.A. Hosner, L.B. Klicka et al. 2015. Avian evolution and speciation in the Southeast Asian tropics. Current Zoology 61(5): 898-900.

Price, T. 1998. Sexual selection and natural selection in bird speciation. Philosophical Transactions of the Royal Society of London B Biological Sciences 353(1366): 251-260.

Rheindt, F.E., J.A. Norman, L. Christidis 2008. DNA evidence shows vocalizations to be a better indicator of taxonomic limits than plumage patterns in Zimmerius tyrant-flycatchers. Molecular Phylogenetic \& Evolution 48(1): 150-156.

Rheindt, F.E., J.A. Eaton \& F. Verbelen. 2011. Vocal trait evolution in a geographic leapfrog pattern: speciation in the Maroon-chinned Fruit Dove (Ptilinopus subgularis) complex from Wallacea. Wilson Journal of Ornithology 123(3): 429-440.

Rheindt, F.E.2016. Earth history and biogeography. In: Eaton, J.A., B. van Balen, N.W. Brickle \& F.E. Rheindt (eds.), Birds of the Indonesian Archipelago Greater Sundas and Wallacea. Barcelona: Lynx Edicions, pp. 9-14.

Rhodin, A.G.J., B.R. Ibarrondo \& G. Kuchling 2008. Chelodina mccordi Rhodin 1994 - Roti Island snakenecked turtle, McCord's snake-necked turtle, KurraKurra Rote. In: Rhodin A.G.J., P.C.H. Pritchard, P.P. van Dijk, R.A. Saumure, K.A. Buhlmann \& J.B. Iverson (eds.), Conservation Biology of Freshwater Turtle and Tortoises: A Compilation Project of the IUCN/ SSC Tortoise and Freshwater Turtle Specialist Group. Chelonian Research Monographs 5.CRF Publications. pp. 008.001-008.008.

RStudio Team. RStudio: Integrated Development for R. Boston, MA: RStudio, Inc; 2015. Available from: http://www.rstudio.com/ [Accessed 10 November 2017].

Sangster, G. \& F.G. Rozendaal 2004. Systematic notes on Asian birds. 41. Territorial songs and species-level taxonomy of nightjars of the Caprimulgus macrurus complex, with the description of a new species. Zoologische Verhandelingen Leiden 350: 7-45.

Searcy, W.A., P. Marler \& S.S. Peters 1981. Species song discrimination in adult female song and swamp sparrows. Animal Behaviour 29(4): 997-1003.

Seneviratne, S.S, I.L. Jones \& S.M. Carr 2012. Patterns of vocal divergence in a group of non-oscine birds (auklets; Alcidae, Charadriiformes). Evolutionary Ecological Research 14(1): 95-112.

Slabbekoorn, H. \& T.B. Smith 2002. Bird song, ecology and speciation. Philosophical Transactions of the Royal Society of London B Biological Sciences 357(1420): 493-503. 
Species factsheet: Myzomela dammermani: BirdLife International; 2017. Available from: http:// www.birdlife.org/ [Accessed 10 November 2017].

Trainor, C.R. 2010. Timor's fauna influence of scale, history and land-use on faunal patterning. PhD. Thesis, Charles Darwin University. Available from: https://espace.cdu.edu.au/view/cdu:9364 [Accessed 10 November 2017].

van Balen, S.B., J.A. Eaton \& F.E. Rheindt 2013. Biology, taxonomy and conservation status of the Shorttailed Green Magpie Cissa [t.] thalassina from Java. Bird Conservation International 23(01): 91-109.

Voris, H.K. 2000. Maps of Pleistocene sea levels in Southeast Asia: Shorelines, river systems and time durations. Journal of Biogeography 27(5): 1153-1167.

White, C.M. \& M.D. Bruce 1986. The Birds of Wallacea (Sulawesi, The Moluccas \& Lesser Sunda Islands, Indonesia): An Annotated Check-list. British Ornithologists' Union, London.

Whittaker, R.J. \& J.M. Fernández-Palacios 2007. Island Biogeography: Ecology, Evolution, and Conservation. $2^{\text {nd }}$ ed. Oxford University Press, Oxford, pp. 22-31.

Wright, C. \& B. Lewis. 2012. On the edge of crisis: contending perspectives on development, tourism, and community participation on Rote Island, Indonesia. Austrian Journal of South-East Asian Studies 5 (1): 102-127.

\section{Supporting information}

Table Supplement 1. Details on 87 sound recordings analysed, including localities, dates of recording and names of sound recordists. The newly described species from Rote is referred to as "Rote Myzomela". The reference number is the accession number for online sound libraries such as Xeno-Canto ornithological sound collection (www.xeno-canto.org) (XC) and the Avian Vocalization Centre (www.avocet.zoology.msu.edu) (AV). Other abbreviations: Internet Bird Collection - IBC, PV - Philippe Verbelen, SC - Stijn Cooleman, JE - James Eaton, DS - David Stewart, RH - Rob Hutchinson, GC Graeme Chapman.

Table Supplement 2. Bioacoustic parameters measured for call types [a] and/or [b] (see Figs. 2 a and b). In our classification of call types, we interpreted an unbroken vocal segment as an "element", whereas a "motif" was taken to be a collection of one to multiple elements that are repeated in an almost identical fashion (Rheindt et al. 2011, Harris et al. 2014, Ng et al. 2016). 